\title{
REMOTE SENSING AND SURFACE ENERGY FLUX MODELS TO DERIVE EVAPOTRANSPIRATION AND CROP COEFFICIENT
}

\author{
Salvatore Barbagallo, Giuseppe Luigi Cirelli, Simona Consoli, Vincenzo Tamburino, Attilio Toscano
}

\section{Introduction}

The estimation of evapotranspiration (ET) and real-time crop coefficient $\left(\mathrm{K}_{\mathrm{c}}\right)$ from irrigated areas is important for water resources planning and regulation. In drought prone regions, high crop water uses coupled with increasing cost for irrigation require appropriate irrigation management to increase water application efficiency (Allen et al., 2005; Douglas et al., 2005). To better estimate water use and more appropriate timing of irrigation, water management practices should account for spatial and temporal variations in plant growth parameters such as vegetation cover, leaf area index and density, and biomass.

High resolution satellite images in visible, near infrared and thermal infrared domains allow to derive relevant indicators of crop water demand for each pixel on areas of regional extent (Colin et al., 2006). In particular, several studies focused on the use of the Normalized Difference Vegetation Index (NDVI) to calculate and map crop coefficient $\left(\mathrm{K}_{\mathrm{c}}\right)$ and evapotranspiration (ET) fluxes (Jackson et al., 1980; Moran et al., 1995; Douglas et al., 2005; Consoli et al., 2006a).

Traditionally, ET has been estimated by multiplying a weather-based reference $\mathrm{ET}_{0}$ by $\mathrm{K}_{\mathrm{c}}$ determined according to the crop type and the crop growth stage (Doorenbos and Pruitt, 1977; Allen et al., 1998). In particular, the FAO-56 publication provides typical development lengths for growth stages and tabularized $\mathrm{K}_{\mathrm{c}}$ values for most agricultural crops. However, local calibration of the $\mathrm{K}_{\mathrm{c}}$ curves are needed to more adequately reflect the crop water uses.

The focus of this paper is to provide a means for improving irrigation scheduling and management using energy balance based ET fluxes and remote sensed

Paper received 20.05.2007; accepted 12.05.2008

SAlvatore Barbagallo, professore ordinario; GiUSEPPE CIRELLI, professore associato; SimONA Consoli, ricercatore, ATTILIO TosCANO, ricercatore. Dipartimento di Ingegneria Agraria, Università degli Studi di Catania. VInCEnzo TAMBURINO, professore ordinario. Dipartimento di Scienze e Tecnologie Agro-Forestali ed Ambientali. Università degli Studi Mediterranea di Reggio Calabria.
$\mathrm{K}_{c}$ data. An empirical approach for determining orange orchards $\mathrm{K}_{\mathrm{c}}$ directly from NDVI observation was provided by the high resolution IKONOS sensor in Eastern Sicily (Italy) during 2006. The performance of the satellite based $\mathrm{K}_{\mathrm{c}}$-NDVI model for estimating ET was evaluated using ground measurements.

\section{Methodology}

\subsection{Field measurements of energy fluxes through canopy coverage}

The surface energy fluxes, meteorological data and radiometric imagery of vegetation used in the study come from an experimental site located in the semiarid Catania Plain irrigation district (Eastern Sicily). The measurement site consisted of a 6 ha orange orchard, where the trees were planted at a distance of $5.0 \mathrm{~m}$ in the row and $5.0 \mathrm{~m}$ between rows for a total of 400 trees per hectare. The orchard was irrigated by means of a low volume irrigation system. The irrigation water is supplied by Salso-Simeto river system; irrigation applications are delivered from collective water distribution networks at fixed intervals and are applied at farm level by micro-sprayers. The data set consists of two Surface Renewal - Energy Balance flux towers (with more than $100 \mathrm{~m}$ of fetch in all the directions) located in the orange orchard area. The two towers were used to increase the consistency of the energy fluxes measurements, and especially of the "uncalibrated" $\mathrm{H}$.

The Surface Renewal (SR) technique (Paw U and Brunet, 1991; Snyder et al., 1996), based on high-frequency air temperature measurements, was used to estimate sensible heat flux density $(\mathrm{H})$. The method has the advantage that temperature or wind speed profiles and corrections for atmospheric stability are unnecessary. It has also the advantage that the equipment is less expensive and more robust than sonic anemometers. In general, the error in SR measurements of $\mathrm{H}$ is similar to the error observed when using a 1-D sonic anemometer (Snyder et al., 1996; Spano et al., 1997).

The sensible heat flux density $(\mathrm{H})$ was used along 
with net radiation $\left(R_{n}\right)$ and soil heat flux $(G)$ data to calculate latent heat flux density (LE) as the residual of the energy balance equation

$$
\mathrm{LE}=\mathrm{R}_{\mathrm{n}}-\mathrm{G}-\mathrm{H}
$$

where $R_{n}$ is a positive number when the net flux is downward (energy added to the surface), LE and $\mathrm{H}$ are positive numbers when the flux is upwards (energy added to the air) and $\mathrm{G}$ is a positive number when the flux is downward (energy added to soil).

High frequency temperature data were collected at $4 \mathrm{~Hz}$ using two $76.2 \mu \mathrm{m}$ diameter fine-wire thermocouples mounted at 0.5 above the canopy top. When plotted the temperature traces show ramp like characteristics, which are used to estimate heat fluxes using a conservation of energy equation (Gao et al. 1989; Paw U et al. 1995; Snyder et al. 1996; Spano et al. 1997). The temperature data were analyzed to determine the mean ramp amplitude (a) and the inverse ramp frequency $(\mathrm{d}+\mathrm{s})$ using a structure function (Van Atta, 1977) and time lags of 0.25 and 0.50 seconds for each of the two thermocouples.

$$
H=a \rho C_{p}\left(\frac{a}{d+s}\right) z
$$

The factor $\alpha$ is a correction term for unequal heating below the sensors that depends on the measurement height (z), on canopy structure and thermocouple size. The symbol $\rho$ is the air density $\left(\mathrm{g} \mathrm{m}^{-3}\right)$ and $\mathrm{C}_{\mathrm{p}}$ is the specific heat of air at constant pressure $\left(\mathrm{J} \mathrm{g}^{-1}\right.$ $\left.\mathrm{K}^{-1}\right)$. Net radiation $\mathrm{R}_{\mathrm{n}}$ was measured using a "Kippen\&Zonen" net radiometer mounted at about $1 \mathrm{~m}$ above the canopy.

Soil heat flux density $G$ was measured using three REBS/HFP01 soil heat flux plates and two Campbell Scientific, Inc. 'CS' ${ }^{\circledR}$ TCAV soil averaging temperature sensors to account for soil heat storage above each heat flux plate. The plates were inserted horizontally into the soil at a depth of $0.05 \mathrm{~m}$, and the soil thermocouples were placed 0.01-0.04 deep. Assuming a moist soil, a volumetric heat capacity $\left(\mathrm{C}_{\mathrm{V}}\right)$ calculated as the product of the apparent soil density and the specific heat of about $2.0 \times 10^{6} \mathrm{MJ} \mathrm{m}^{3} \mathrm{~K}^{-1}$ was used to compute changes in heat storage $(\Delta S)$ above the flux plates.

$$
\Delta S-C v\left(\frac{T_{f}-T_{i}}{1800}\right) d
$$

where $T_{f}$ and $T_{i}$ are the final and the initial temperature for half-hour period and $\mathrm{d}=0.05$ is the depth of the heat flux plate. The value 1800 is the number of seconds per half-hour. The soil heat flux density at $0.04 \mathrm{~m}$ depth $\left(\mathrm{G}_{0}\right)$ was calculated as the mean of the three heat flux plate measurements. The soil heat flux density at the surface $(\mathrm{G})$ was calculated as

$$
\mathrm{G}=\Delta \mathrm{S}+\mathrm{G}_{0}
$$

In combination, half-hourly data on $H, R_{n}$ and $G$ were used to calculate latent heat flux density (LE) as the residual of the energy balance (EB) equation. The actual crop ET (ETas $)$ was computed by dividing hourly means of LE by the latent heat of vaporization $\mathrm{L}=2.45 \mathrm{MJ} \mathrm{m}^{-2} \mathrm{~mm}^{-1}$. Generally, crop coefficients are determined by calculating the ratio $\mathrm{K}_{\mathrm{c}}=\mathrm{ET}_{\mathrm{p}} / \mathrm{ET}_{\mathrm{o}}$, where $\mathrm{ET}_{\mathrm{p}}$ is the evapotranspiration of a well-watered crop. Since the orchards under study are pretty well managed, it is assumed that there was little or no transpiration reducing water stress and $\mathrm{ET}_{\mathrm{a}} \approx \mathrm{ET}_{\mathrm{p}}$. Therefore, hourly variations of crop coefficient $\left(K_{c}^{\mathrm{p}}\right)$ values, during the monitoring period, were determined using $\mathrm{ET}_{\mathrm{a}}$ and reference evapotranspiration $\left(\mathrm{ET}_{\mathrm{o}}\right)$ (ASCE_EWRI, 2004). Hourly weather data used to calculate the Penman-Monteith reference evapotranspiration $\mathrm{ET}_{0}$ for short crops (ASCE_EWRI, 2004; Allen et al., 2006) included solar radiation $\left(\mathrm{R}_{\mathrm{s}}\right)$, air temperature $(\mathrm{T})$, relative humidity $(\mathrm{RH})$, wind speed $\left(\mathrm{u}_{2}\right)$ and direction (WD). The climatic data (including rainfall, P), recorded from January through October 2006, came from the CR10X weather station (Campbell Scientific, Logan, UT) located at the experimental field. Hourly $\mathrm{ET}_{0}$ values were summed over 24hour periods to obtain daily $\mathrm{ET}_{0}$ data.

$$
\mathrm{ET}_{0}=\frac{0,408 \Delta\left(k_{n}-G\right)+\gamma \frac{37}{T+273}{ }^{112}\left(c_{8}-c_{9}\right)}{\Delta+\lambda\left(1+0.24 u_{2}\right)}
$$

In the eq., $\Delta$ is the slope of the saturation vapour pressure at the air temperature $\left(\mathrm{kPa}^{\circ} \mathrm{C}^{-1}\right), \gamma$ is the psychrometric constant $\left(\mathrm{kPa}^{\circ} \mathrm{C}^{-1}\right)$ and $\mathrm{e}_{\mathrm{s}}-\mathrm{e}_{\mathrm{a}}$ is the vapour pressure deficit $(\mathrm{kPa})$.

\subsection{A semi-empirical approach to produce ET and $K_{c}$ maps}

Spectral observations on canopy reflectance were acquired using the high resolution IKONOS sensor (Table 1). Two images from the sensor were acquired for the study area during July $6^{\text {th }}$ and August $17^{\text {th }}$ 2006 (Figure 1).

The evaluation of evapotranspiration for the operational assessment of crop water requirements was made using the following procedures defined by FAO (Allen et al., 1998; ASCE_EWRI, 2004; Allen et al., 2006): i) the crop coefficient $K_{c}$ was defined as the ratio of potential evapotranspiration $\mathrm{ET}_{\mathrm{p}}$ by reference evapotranspiration $\mathrm{ET}_{0}$; ii) the evapotranspiration fluxes (potential and reference) were calculated using the modified Penman-Monteith (eq. 5) approach with appropriate values of canopy variables such as crop height, surface albedo and leaf area index (LAI). In particular, the canopy variables needed for calculating reference crop water requirements under standard conditions (adequate soil water supply) were extracted from tables (Doorenbos and Pruitt, 1977) in the case of the $\mathrm{ET}_{0}$ estimation, while they were derived from remote observations in the case of $\mathrm{ET}_{\mathrm{p}}$ (eqs. from 6 to 8 ).

The value of crop height $\left(h_{c}\right)$ for the calculation of ET $_{\mathrm{p}}$ was assumed constant and equal to $0.6 \mathrm{~m}$. This choice stems from the consideration that the radiation 


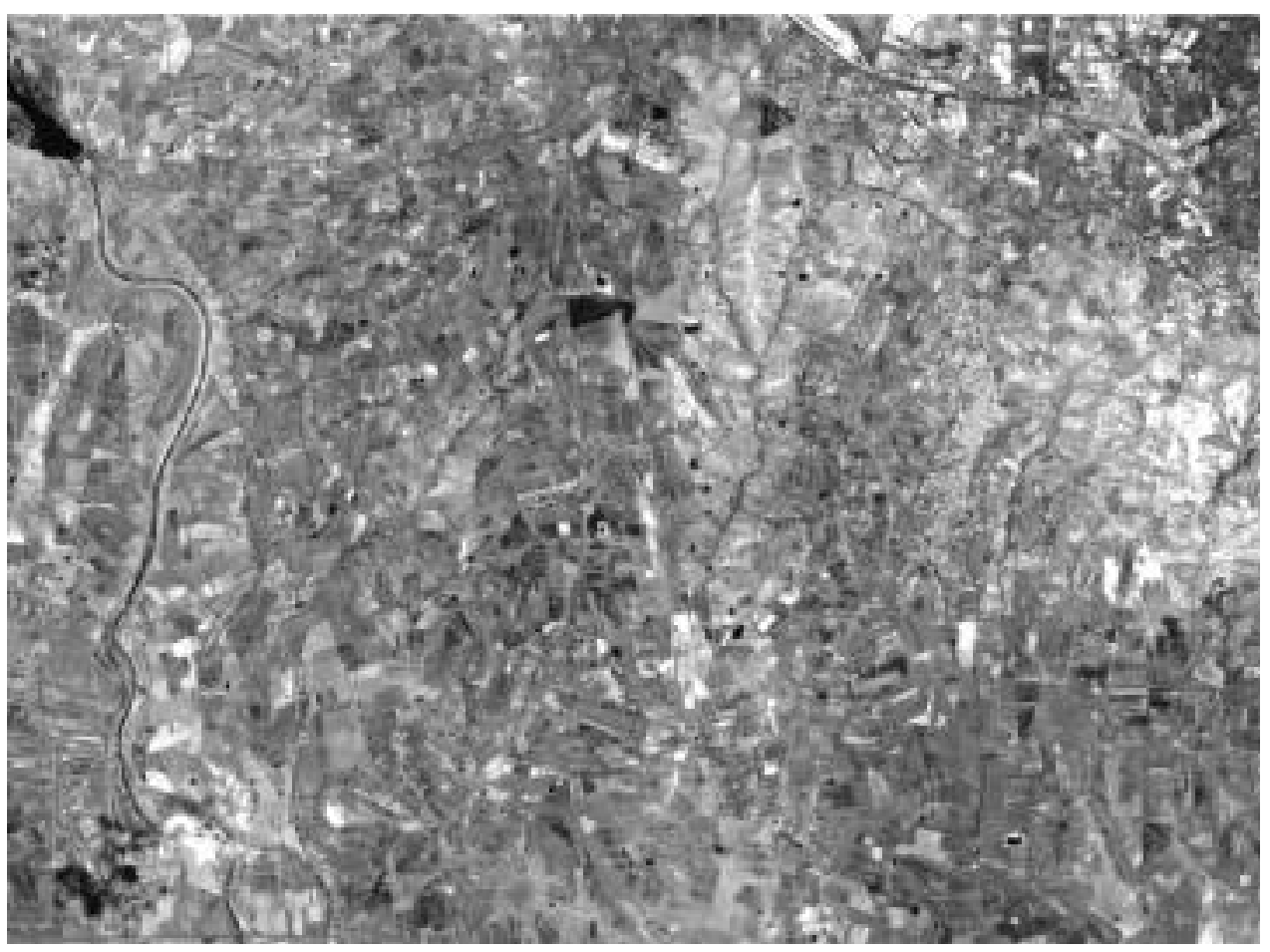

Fig. 1 - IKONOS image - August $17^{\text {th }} 2006$

term is prevailing in the energy budget of this area and that a constant $h_{c}$ does not affect the accuracy of estimation to a great extent. To check this assumption, a sensitivity analysis to $h_{c}$ with the values of Leaf Area Index was made (Barbagallo et al., 2002; Consoli et al., 2006b). In particular, the deviation on ET values by considering a constant value of $h_{c}$, on $a$ wide range of Leaf Area Index, is maintained lower than $10 \%$.

Simple and feasible approaches based on empirical relationships between LAI and reflectance data in red and infrared bands of the electromagnetic spectrum have been defined by several authors (Clevers, 1989; D'Urso et al., 2001). In the study LAI was related to WDVI (Weighted Difference Vegetation Index) of the observed surface through the expression

$$
\mathrm{LAI}=-\frac{1}{\alpha^{*}} \ln \left(1-\frac{\text { WDVI }}{\mathrm{WDVI}_{\infty}}\right)
$$

where:

$$
\text { WDVI }=\rho_{\mathrm{i}}-\rho_{\mathrm{r}} \cdot \frac{\rho_{\mathrm{si}}}{\rho_{\mathrm{st}}}
$$

The symbols $\rho_{\mathrm{r}}, \rho_{\mathrm{i}} \rho_{\mathrm{sr}}, \rho_{\mathrm{si}}$ represent the reflectance in the red and infrared region for the vegetation and the soil respectively. In eq. $6, \alpha^{*}$ is an extinction coefficient determined using field measurements of LAI by inversion of eq. 6 , considering the corresponding WDVI.

The albedo $r$ was calculated using eq. 8 (Menenti, 1984), where $\mathrm{w}_{\lambda}$ are weighted percentages of the extraterrestrial solar irradiance $E_{0 \lambda}$ in each band of the sensor.

$$
r=\sum_{\lambda} w \lambda \cdot \rho_{\lambda}
$$

In the study, a procedure for the estimation of crop water requirement from Earth Observation data has been developed and tested. The method is based on the relationship between the Normalized Difference Vegetation Index (NDVI) and the values of $\mathrm{K}_{c}$. The NDVI represents one of the most spread reflection index for vegetation monitoring (D'Urso and Belmonte, 2006). It is calculated from the surface reflectance in near-infrared $\rho_{i}$ and in the red band $\rho_{r}$, by means of the following relation ship:

$$
\text { NDVI }=\frac{\rho_{\mathrm{i}}-\rho_{\mathrm{r}}}{\rho_{\mathrm{i}}+\rho_{\mathrm{r}}}
$$

The ability of NDVI to describe canopy biophysical properties has been shown by several applied researches. In particular, NDVI was related linearly with the fractional vegetation cover (Calera et al., 2001) and with the fraction of absorbed photosynthetically active PAR radiation (Sellers et al., 1997);

\begin{tabular}{|l|l|l|l|l|}
\hline Sensor & $\begin{array}{l}\text { Spatial } \\
\text { resolution } \\
(\mathrm{m})\end{array}$ & Band & $\begin{array}{l}\text { Bands range } \\
(\mu \mathrm{m})\end{array}$ & $\begin{array}{l}\text { Solar } \\
\text { irradiance } \\
E_{\lambda}^{0} \\
\left(\mathrm{~W} \mathrm{~m}^{-2}\right)\end{array}$ \\
\hline & & Blue & $0.45-0.52$ & 141.88 \\
IKONOS & 4.0 & $\begin{array}{l}\text { Green } \\
\text { Red } \\
\text { NIR }\end{array}$ & $\begin{array}{l}0.52-0.6 \\
0.63-0.69\end{array}$ & $\begin{array}{l}169.95 \\
0.76-0.9\end{array}$ \\
& & & & \\
& & &
\end{tabular}

TABLE 1 - IKONOS sensor characteristics. 


\begin{tabular}{|l|l|l|l|l|l|}
\hline $\begin{array}{l}\text { Crop } \\
\text { Type }\end{array}$ & Period & $\begin{array}{l}\text { LAI } \\
\left(\mathrm{m}^{2} \mathrm{~m}^{-2}\right)\end{array}$ & $\begin{array}{l}\text { Crop } \\
\text { height } \\
(\mathrm{m})\end{array}$ & $\begin{array}{l}\mathrm{Cg} \\
(\%)\end{array}$ & $\begin{array}{l}\mathrm{f}_{\mathrm{PAR}} \\
(\%)\end{array}$ \\
\hline $\begin{array}{l}\text { Orange } \\
\text { Orchard }\end{array}$ & $\begin{array}{l}\text { June- } \\
\text { August } \\
2006\end{array}$ & $1.5-2.3$ & 4.0 & $50-70$ & $70-80$ \\
\hline
\end{tabular}

TABLE 2 - Crop type, period of time, location and biophysical variables measured during the field campaign.

moreover it is related exponentially with LAI (Gilabert et al., 1996). NDVI values, estimated as in eq. 9, were paired with $\mathrm{K}_{\mathrm{c}}$ values derived using the satellite approach. As reported by other researches, a linear correlation between $\mathrm{K}_{c}$ and NDVI was adopted.

The $\mathrm{K}_{\mathrm{c}}$-NDVI model was verified by the acquisition, during late August 2006, of hyper-spectral reflectance data using an Analytical Spectral Device (FieldSpec UV/VNIR). In particular, reflectance in red and near infrared to compute NDVI was obtained by integrating spectral reflectance in the range 0.63 0.69 and $0.76-0.86 \mu \mathrm{m}$. In selected ground control sites, residuals calculated from the soil water balance (SWB) equation were used to determine actual evapotranspiration $\left(\mathrm{ET}_{\mathrm{a}}\right)$ values, assuming negligible drainage below the crop root zone. Measured $\mathrm{K}_{\mathrm{c}}$ were obtained by the ratio between the SWB-based ET and $\mathrm{ET}_{0}$ of eq. (5).

Because of the limited frequency of the images, in the study weekly, fortnightly or monthly ET $\mathrm{ET}_{\mathrm{p}}$ were estimated by linearly interpolating the variable values for periods in between two consecutive images, in the same spatial resolution as the original satellite images (D’Urso, 2001; Barbagallo et al., 2002; Consoli et al., 2006b).

$$
\begin{aligned}
& E T_{p}(d)=E T_{0}(d)\left\{\frac{E T_{p}\left\langle d_{1}\right)}{E T_{0}\left\langle d_{1}\right)}+\left[\frac{E T_{p}\left(d_{2}\right)}{E T_{0}\left(d_{2}\right)}-\frac{E T_{p}\left(d_{1}\right)}{E T_{0}\left(d_{1}\right)}\right] \frac{d-d_{1}}{d-d_{2}}\right\} \\
& \forall d \in\left[d_{1} ; d_{2}\right]
\end{aligned}
$$

With a fortnightly frequency during the period June-August 2006 and in coincidence to the spectral observation, other biophysical parameters were measured: crop height, leaf area index, percentage of ground cover $\left(\mathrm{C}_{\mathrm{g}}\right)$ and absorbed photosynthetically active radiation $\left(\mathrm{f}_{\mathrm{PAR}}\right)$. In table 2 there is a description of the variables measured during the field campaigns. The percentage ground cover $\left(\mathrm{C}_{\mathrm{g}}\right)$ was estimated from the tree size relative to tree spacing in the orchards. The area shaded by a tree was estimated as the product of length of foliage within the row and the width of foliage across the row. This was divided by the area per tree within the orchard (distance between rows $x$ distance between trees within a row) to estimate the percentage ground cover

\section{Results and discussion}

\subsection{ET fluxes from the energy balance approach}

Figure 2 shows the energy balance calculations during June - October 2006. The daily mean $\mathrm{H}$ ranged between zero and $3.4 \mathrm{MJ} \mathrm{m}^{-2} \mathrm{~d}^{-1}$ with an average of about $2.2 \mathrm{MJ} \mathrm{m}^{-2} \mathrm{~d}^{-1}$ and a high variability $(\mathrm{Cv})$ of $30 \%$. Just before the irrigation application LE values reveal a significant hourly variability from day to night that may be ascribed to a sub-optimal water supply to the orchard stands. LE presents an average of about $11.2 \mathrm{MJ} \mathrm{m}^{-2} \mathrm{~d}^{-1}$, with a variability $(\mathrm{Cv}=15 \%)$ between 2.6 and $17.4 \mathrm{MJ} \mathrm{m}^{-2} \mathrm{~d}^{-1}$. Mean values of daily

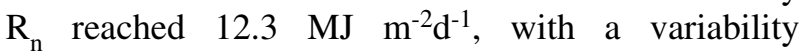
$(\mathrm{Cv}=17 \%)$ from a maximum of 19.2 to a minimum of 1.7 $\mathrm{MJ} \mathrm{m}^{-2} \mathrm{~d}^{-1}$. The lower $\mathrm{R}_{\mathrm{n}}$ values were most likely due to greater albedo and higher surface temperatures for the orchards (the latter reached about $33^{\circ} \mathrm{C}$ as measured by a Thermal Infrared (TIR) sensor). Average values of solar radiation $\left(R_{s}\right)$ near $18.7 \mathrm{MJ} \mathrm{m}^{-2} \mathrm{~d}^{-1}$ were recorded during the monitoring. On a daily basis, the $\mathrm{G}$ term is generally close to zero.

Daily $\mathrm{ET}_{0}$ were between $0.9-10 \mathrm{~mm}$, with a mean value of $5.2 \mathrm{~mm} \mathrm{~d}^{-1}$. Daily $\mathrm{ET}_{\mathrm{a}}$ values were lower than $8.0 \mathrm{~mm}$ with an average of about $4.6 \mathrm{~mm}$ and a variability of $30 \%$. Average value of the daily crop coefficient was about 0.91 with a variability of about $20 \%$. The value is higher than the $\mathrm{K}_{\mathrm{c}}$ data reported in

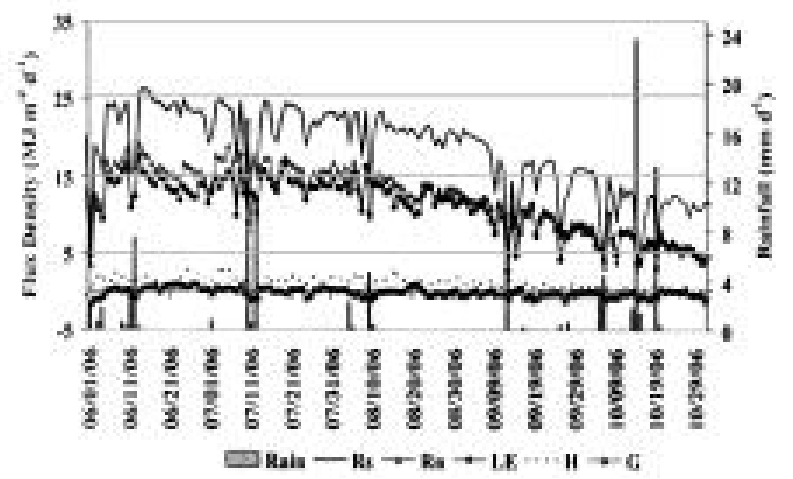

Fig. 2 - Daily energy balance components and rainfall during JuneOctober 2006.

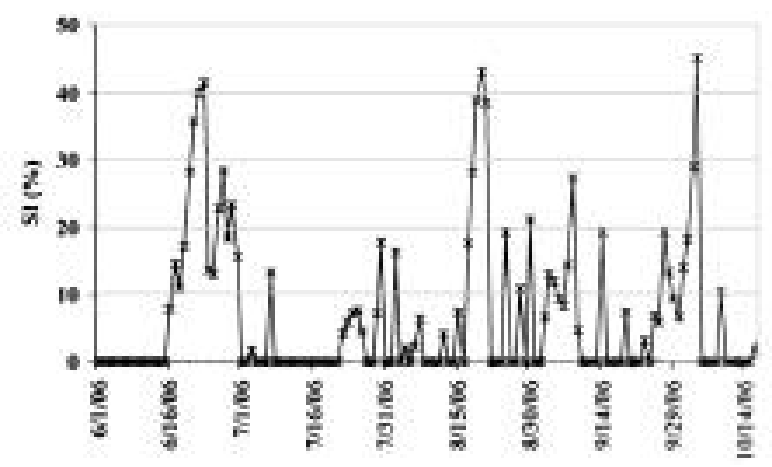

Fig. 3 - Distribution of the stress index (SI, \%) during June-October 2006 . 
the widely used FAO 56 (Allen et al., 1998) and FAO 24 (Doorenbos and Pruitt, 1977), that report a maximum $\mathrm{K}_{\mathrm{c}}$ between 0.65 to 0.70 for orchards with ground cover of $70 \%$ during summer and fall. Similar results were discussed in the applied researches carried out by Hoffman et al. (1980), Rogers et al. (1983) and Consoli et al., (2006b).

By using the mean daily crop coefficient $\mathrm{K}_{\mathrm{c}}$ during July (equals to 0.96), the normalized Stress Index (Consoli et al., 2006c) was plotted in Figure 3.

$$
S I=100 \times\left[1-\frac{E T_{a}}{E T_{p}}\right]
$$

where $\mathrm{ET}_{\mathrm{p}}$ is the value of crop ET for a grove that is not limited by the available moisture. The ET $\mathrm{ET}_{\mathrm{p}}$ values were determined by using the mean daily value of $\mathrm{K}_{\mathrm{c}}$ during July (when the orchard stands were well watered) and the $\mathrm{ET}_{0}$ on each day of the monitored period. The orchard may have been under water stress on days that observed $\mathrm{ET}_{\mathrm{a}}$ was less that the $\mathrm{ET}_{\mathrm{p}}$ value. On days with measurable precipitation or irrigation,

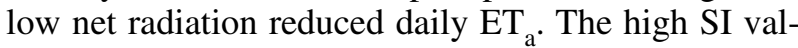
ues (about 45\%) might result also from a combination of additional sensible heat from the exposed, dry orchard floor and from reflection of short wave radiation from off the soil surface into the trees.

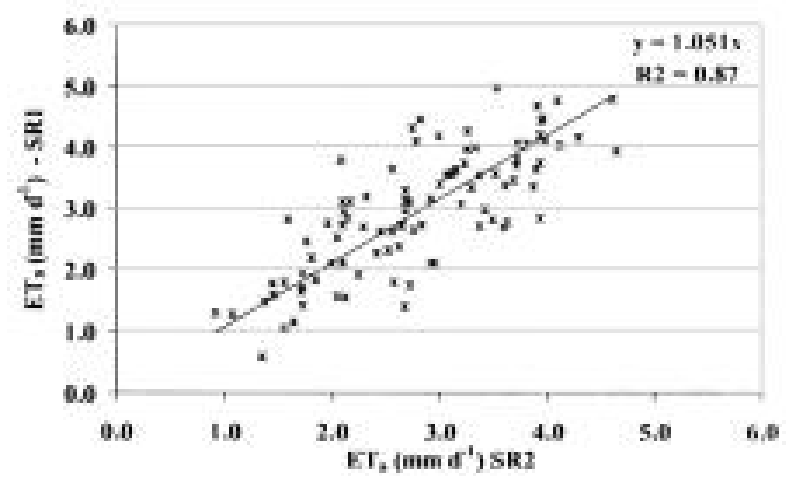

Fig. 4 - Regression of daily averages of ET from SR1 and SR2 during June-October 2006.

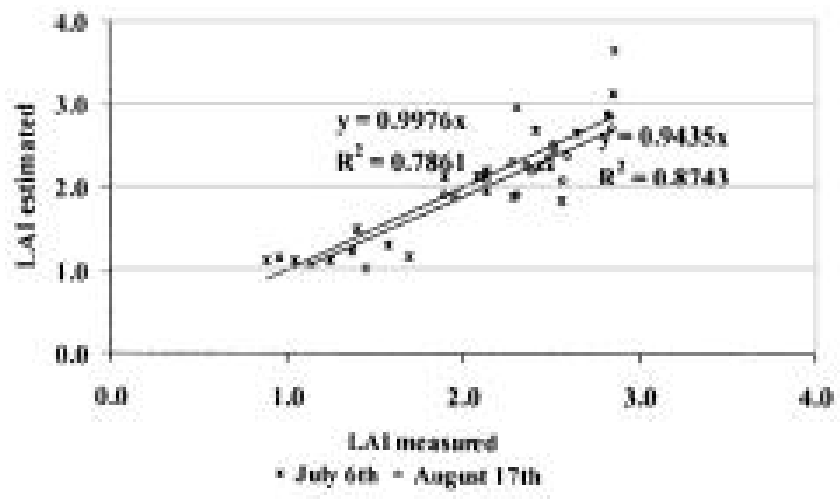

Fig. 5 - Validation of the empirical relationship for LAI using the image of July $6^{\text {th }} 2006$ (a) and August $17^{\text {th }} 2006$.
Figure 4 shows the regression of daily averages of actual evapotranspiration $\left(\mathrm{ET}_{\mathrm{a}}\right.$ ) from the two Surface Renewal stations (named SR1 and SR2) during the monitored period.

\subsection{Kc-NDVI remote sensing based model}

Atmospherically corrected reflectance values were derived by means of the ATCOR procedure (Richter et al., 2002) assuming constant atmospheric conditions over the images and different types of standard atmospheric profiles. The satellite images were geometrically rectified to the Universal Transversal Mercator projection system (UTM), by using a linear transformation of coordinates and the nearest-neighbour resampling method for the pixel reflectance values (Jensen, 1986).

By using field measurement data sets collected during 2006, calibration and validation of Eq.(6) have been carried out. The soil and vegetation reflectance acquisition through IKONOS images has produced a $\rho_{\mathrm{si}} / \rho_{\mathrm{sr}}$ equals to 0.75 , with $\alpha^{*}$ between 0.16 and 0.37 during July $6^{\text {th }}$ and August $17^{\text {th }}$, respectively and WD$\mathrm{VI} \infty=0.64$. Differences on $\alpha^{*}$ values during the monitored period were related to the increase on the amount of vegetation (WDVI) within the study area.

Average values of LAI were detected around 2.0; generally mean errors between measured and estimated LAI values resulted of about $20 \%$ (Figure 5). Albe$d o$ 's values varied between 0.12 and 0.28 with an average of 0.19 and a variation of $20 \%$. The remote estimates of $r$ were found in good accordance with r's data derived from the Surface Renewal stations and with data reported from literature (Russel et al., 1997).

Spatial variability of green vegetation cover was obtained for the monitored area by evaluating vegetation indicators (NDVI, WDVI).

As evidenced by Figure 6, in average WDVI and NDVI values present a certain variability between different control points (about 4 pixels each) selected in the images. Spatially, during satellite acquisitions mean values of WDVI and NDVI varied between 0.25 and 0.15 and from 0.32 and 0.10 , respectively. WDVI and NDVI mean values resulted increasing

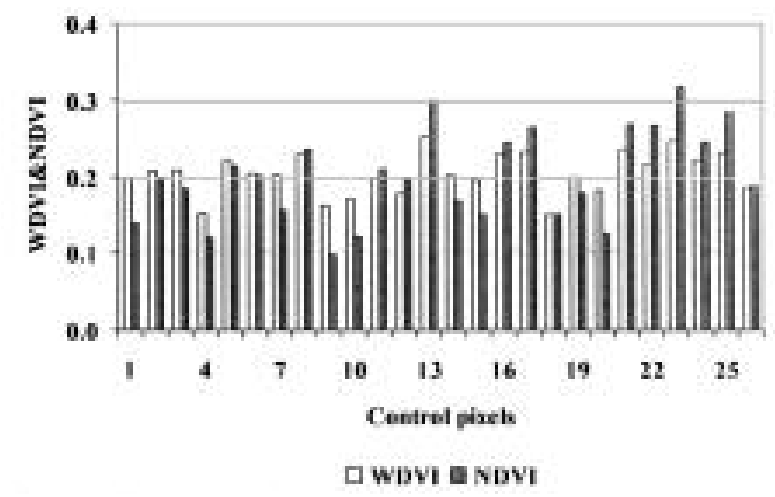

Fig. 6 - Spatial variability of the vegetation indices WDVI and NDVI during IKONOS satellite acquisition in 2006. 
from July to August of about $30 \%$, due to the development of the orchard foliage pruned in late May 2006. Satellite estimates of ET (see Eq. 10) reached mean values of about $4.7 \mathrm{~mm} \mathrm{~d}^{-1}$, with a maximum of about $6.4 \mathrm{~mm} \mathrm{~d}^{-1}$ and a minimum of $2.9 \mathrm{~mm} \mathrm{~d}^{-1}$. Crop coefficient data reached maximum values of about 0.85 , with a mean around 0.8 during the period from July $6^{\text {th }}$ and August $17^{\text {th }} 2006$ (Figure 7).

In the analysis of ET fluxes and $\mathrm{K}_{\mathrm{c}}$ data by remote sensing, it may be underlined that, considering an average distance between the trees in this area of $5 \mathrm{~m}$; at full development (which corresponds to tree height of 3.5-4.0 $\mathrm{m}$ and a LAI of 2-2.5) the fractional vegetation cover is almost $100 \%$. Thus the IKONOS sensor, with a resolution lower than $5 \mathrm{~m}$, is able to distinguish individual trees except for the case of fully developed orchards.

Linear correlations express the increase in $\mathrm{K}_{\mathrm{c}}$ with NDVI through the monitored period. The linear trend presents a determination coefficients $\left(\mathrm{R}^{2}\right)$ higher than 0.90 , with minimal scatter around the regression lines (Figure 8). It must be inferred that the relationship $\mathrm{K}_{\mathrm{c}}$ NDVI is strictly related to the selected crop and the specific conditions of the area under experiment. Furthermore, it is well suited to be applied for orchard crops characterized by pretty steady LAI values.

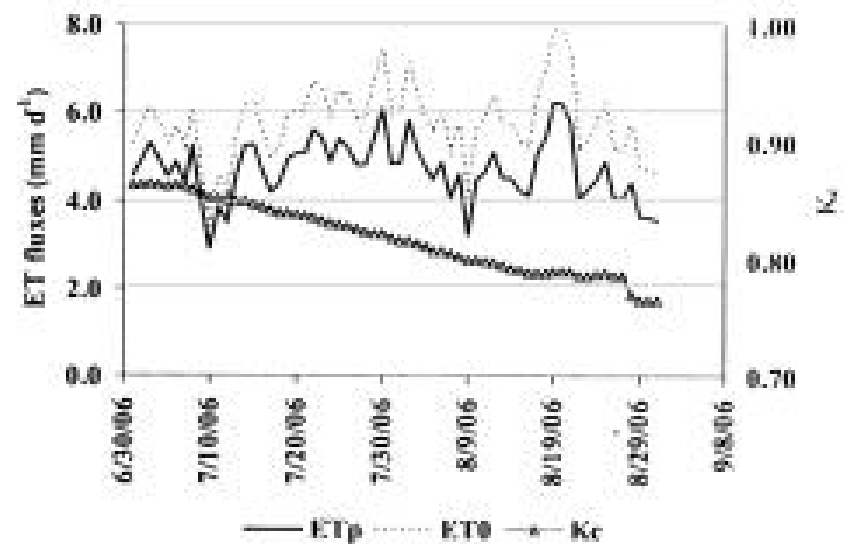

Fig. 7 - Time distributions of ET fluxes and $\mathrm{K}_{\mathrm{c}}$ values

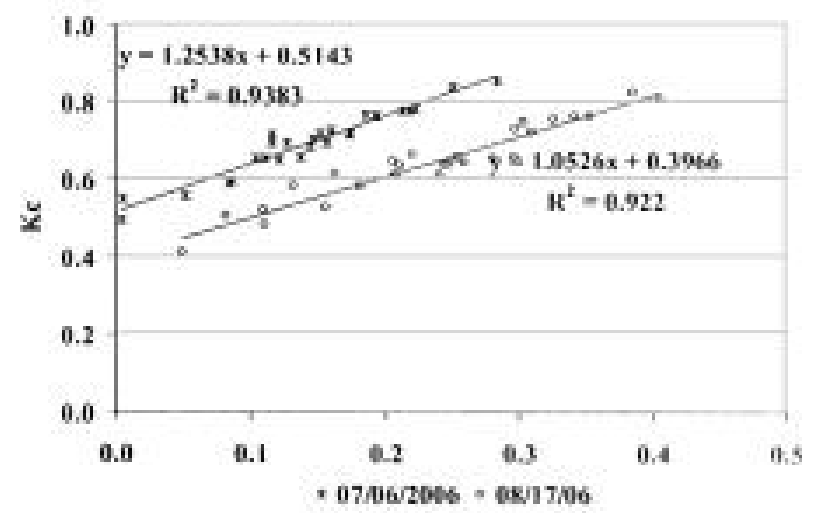

Fig. $8-\mathrm{K}_{\mathrm{c}}$-NDVI models from IKONOS reflectance data.

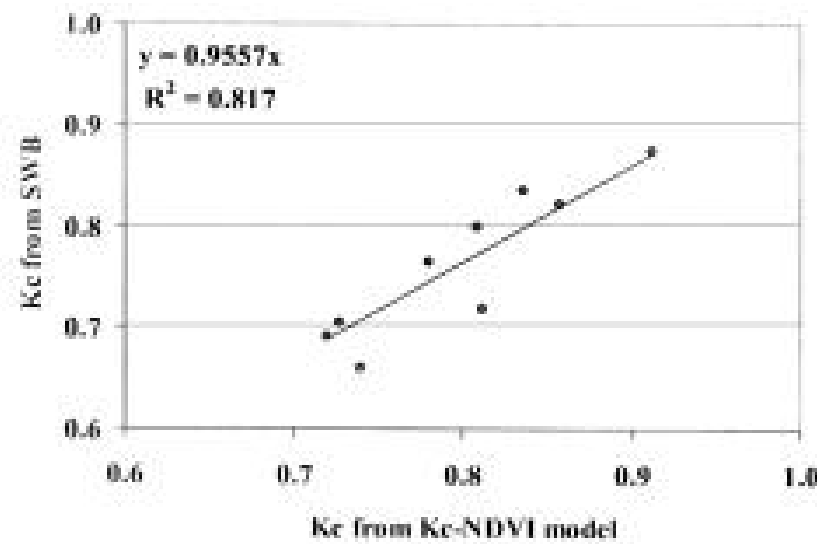

Fig. 9 - Plotted $\mathrm{K}_{\mathrm{c}}$ data derived from the $\mathrm{K}_{\mathrm{c}}$-NDVI model versus $\mathrm{K}_{\mathrm{c}}$ from SWB.

The $\mathrm{K}_{\mathrm{c}}$-NDVI models have been checked (Figure 9) during the field campaign of late August 2006. Good agreement has been found for crops with an high fractional vegetation cover (points falling in the regression line). Deviation between NDVI-based and FAO-56 based $\mathrm{K}_{\mathrm{c}}$ was detected.

To conclude, some comparisons between ET fluxes and $\mathrm{K}_{\mathrm{c}}$ values obtained from SR-EB technique and from Remote Sensing approach will follow. In particular, during the spectral observation period in 2006 average values of $\mathrm{ET}_{\mathrm{p}}$ equal to $4.7 \mathrm{~mm} \mathrm{~d}^{-1}$ were found in good accordance with $\mathrm{ET}_{\mathrm{a}}$ fluxes measured using the Surface Renewal stations. Differences were detected in terms of crop coefficient $\left(\mathrm{K}_{\mathrm{c}}\right)$, that reached mean values of about 0.90 and 0.80 using Surface Renewal technique and the Remote Sensing approach, respectively. Care must be made in stating the different natures of both types of concepts (satellite-based reflectance potential ET data and energy balance actual ET measurements) and the limitation of such comparison.

\section{Conclusions}

A reliable monitoring of crop water demand at field scale requires remote sensing systems having high spatial resolution and a fairly short return time. In this study, a semi-empirical approach was applied to IKONOS images acquired during July and August 2006, to provide maps of ET related variables over an agricultural area in Eastern Sicily (Italy). $\mathrm{K}_{\mathrm{c}}$-NDVI models were applied to provide daily maps of ET fluxes using remote sensed reflectance data from the monitored vegetation (orange orchards). Irrigation components $\left(\mathrm{ET}, \mathrm{K}_{\mathrm{c}}\right)$ estimation using satellite data was compared with Surface Renewal - Energy Balance measurements from agricultural settings. Nevertheless, relevant information has resulted from this analysis, and a fairly good agreement between methods is observed. Regarding the daily values of crop water demand, results from the $\mathrm{K}_{\mathrm{c}}-\mathrm{NDVI}$ and SR-EB approaches are higher than those suggested by FAO 56. 
The semi-empirical procedure described here could be implemented in order to provide reliable and useful products to farmers and/or to collective irrigation systems about crop water requirements. For operational purposes, in fact, in an area with smaller farms, IKONOS has proven to be a viable (yet more costly) option since it also provides the necessary higher spatial resolution, with available rush service.

To conclude, EOS techniques are ready of being transferred to operative applications of great impact on the management of water and land resources. With this purpose, very interesting researches were carried out within the DEMETER project on the operational spaceassisted irrigation advisory services (Jochum et al., 2005) and more recently the spin-off of the University of Napoli Federico II is working on a regional support service for irrigation scheduling by using satellite data.

To conclude, about the Surface Renewal station, the big advantage of the method is the low cost (i.e. if compared with the eddy covariance technique) and simple instrumentation. The instrumentation and theory are simple, but the calculations are complex. However, once the analysis software is available the technique is easy to employ.

\section{Acknowledgment}

The study was carried our within the AQUATEC project (2001-2006), founded by the European Union and the Italian Minister of Education and Research. The Authors contributed to the study with equal effort.

\section{References}

[1] Allen R.G., Pereira L.S., Raes D., Smith M., Crop evapotranspiration: Guidelines for computing crop water requirements, FAO Irrig Drain Paper n. 56, FAO, (1998) Rome, Italy.

[2] Allen R.G., Tasumi M., Morse A., Trezza R., A Landsat-based energy balance and evapotranspiration model in western US water rights regulation and planning Irr. Drain. Syst. (2005) Vol. 19, pp. 251268.

[3] Allen R.G., Tasumi M., Trezza R., Benefits from tying satellite-based energy balance to reference evapotranspiration In: Earth Observation for Vegetation Monitoring edited by G. D'Urso, M.O. Osann Jochum, and J. Moreno, American Institute of Physics (2006).

[4] ASCE-EWRI, The ASCE Standardized Reference Evapotranspiration Equation, Technical Committee report to the Environmental and Water Resources Institute of the ASCE from the Task Committee on Standardization of Reference Evapotranspiration, (2004) 173p.

[5] Barbagallo S., Consoli S., D’Urso S., Toscano A., Valutazione delle prestazioni di sistemi irrigui mediante tecniche di telerilevamento: applicazione ad un comprensorio irriguo siciliano, Proceedings of the XXVIII Convegno di Idraulica e Costruzioni Idrauliche Potenza, Italy, September, 2002
[6] Calera A., Martinez C., Melia J., A procedure fro obtaining green plant cover: relaion to NDVI in a case study for Barley Int. J. Remote Sens. (2001) Vol. 22(17), pp. 3357-3362.

[7] CleVERS J.G.P.W., The application of a weighted infrared-red vegetation index for estimation leaf area index by correcting for soil moisture Remote Sens. Environm., (1989) Vol. 29, pp. 25-37.

[8] Colin J., Menenti M., Rubio E., Jochum A., A multiscale surface energy balance system for operational actual surface evapotranspiration monitoring In: Earth Observation for Vegetation Monitoring edited by G. D'Urso, M.O. Osann Jochum, and J. Moreno, American Institute of Physics (2006).

[9] Consoli S., Cirelli G.L., Toscano A., Monitoring crop coefficient of orange orchards using energy balance and the remote sensed NDVI Proceedings of the Conference on "Remote Sensing for Agriculture, Ecosystems, and Hydrology", Stockolm, Sweden, September (2006a).

[10] Consoli S., D’URso G. Toscano A., Remote sensing to estimate ET-fluxes and the performance of an irrigation district in Southern Italy, Agric. Wat. Manag. (2006b) Vol. 81, pp. 295-314.

[11] Consoli S., O'Connell N.V., SNyder R.L., Estimation of evapotranspiration of different orange sized orchard canopies using energy balance J. Irr. Drain. Eng., ASCE, (2006c) Vol. 132(1), pp. 2-8.

[12] Doorenbos J., PRuitT W.O., Crop water requirements. FAO Irrig Drain Paper n. 24 revised, FAO, (1977), Rome, Italy.

[13] Douglas J. H., Pinter JR P.J., Barnes E.M., KimBALL B.A., Wheat basal crop coefficients determined by normalized difference vegetation index Irrig Sci (2005) Vol. 24, pp. 1-14.

[14] D'Urso G., Simulation and Management of On-Demand Irrigation Systems: a combined agro-hydrological approach Ph.D. Thesis, Wageningen University, (2001) 174pp.

[15] D’Urso G., Calera Belmonte A., Operative approaches to determine crop water requirements from earth observation data: methodologies and applications In: Earth Observation for Vegetation Monitoring edited by G. D'Urso, M.O. Osann Jochum, and J. Moreno, American Institute of Physics, (2006).

[16] Gao W., Shaw R.H., Paw U K.T., Observation of organized structure in turbulent flow within and above a forest canopy, Bound.Layer Met. (1989) Vol. 47, pp. 349-377.

[17] Gilabert M.A., Gandia S., Melia J., Analyses of spectral-biophysical relationships for a corn canopy Remote Sens. Environm. (1996) Vol. 55, pp. 11-20.

[18] Hoffman G.J., Oster J.D., Alves W.J., Evapotranspiration of mature orange trees in an arid climate. Summer meeting of the Amer. Soc. Agric. Eng., San Antonio, Texas, June 15-18, (1980).

[19] Jackson R.D., IDSo S.B., Reginato R.J., Pinter JR P.J., Remotely sensed crop temperatures and reflectances as input to irrigation scheduling In: Irr. Drain. special conference proceedings, 23-25 July (1980), Boise, Idaho. ASCE, New York, pp. 390-397

[20] JENSEN J.R., Introductory digital image processing. A remote sensing perspective Prentice-Hall, Englewood Cliff, N.J., U.S.A. (1986).

[21] Jouchum M.A.O., Calera A. AND ALl Demeter PARTENERS, Operational space-assisted irrigation ad- 
visory services: overview of and lessons learned from the project DEMETER, In: Earth Observation for Vegetation Monitoring edited by G. D’Urso, M.O. Osann Jochum, and J. Moreno, American Institute of Physics, (2006).

[22] Menenti M., Physical aspect and determination of evaporation in desert applying remote sensing techniques, ICW Report n.10 (Special issue), (1984).

[23] Moran M.S., Mass S.J., PINTER JR P.J., Combining remote sensing and modelling for estimating surface evaporation and biomass production Remote Sens. Rev. (1995) Vol. 12, pp.335-353.

[24] Paw U K.T., Qiu J., Su H.B., Watanabe T., Brunet Y., Surface renewal analysis: a new method to obtain scalar fluxes without velocity data Agric. For. Meteorol. (1995) Vol. 74, pp. 119-137.

[25] Paw U K.T., BRunet Y., A surface renewal measure of sensible heat flux density Proc. of the 20th Conference on Agriculture and Forest Meteorology, Salt Lake City, (1991), pp. 52-53.

[26] Richter R., Mueller A., Heiden U., Aspects of operational atmoshperic correction of hyperspectral imagery Int. J. Remote Sens. (2002) Vol. 23, pp. 145157.

[27] Rogers J.S., Allen JR L.H., AND CAlVert D.V., Evapotranspiration from a humid-region developing citrus grove with a grass cover. Trans of the ASAE, (1983) Vol. 26 (6), pp. 1778-1783.

[28] Russel, M.J., Nunez, M., Chladil, M.A., Valiente, J.A., LOPEZ-BAEZA, E., Conversion of Nadir, narrowband reflectance in red and near-infrared channels to hemispherical surface albedo. Remote Sens. Environm., (1997) Vol. 61, 16-23.

[29] Sellers P.J., Dickinson R.E., Randall A., Betts A.K., Hall F.G., Berry J.A., Collatz G.J., Denning A.S., Mooney H.A., Nobre C.A., Sato N., Field C.B. Henderson-Sellers A., Modelling the exchange of energy, water and carbon between continents and the atmosphere Science, (1997) Vol. 275, pp. 52-509.

[30] SNYDER R.L., SPANO D., PAW U K.T., Surface Renewal analysis for sensible and latent heat flux density Bound. Layer Meteorol. (1996) Vol. 77, pp. 249-266.
[31] Spano D., Snyder R.L., Duce P., Paw U K.T., Surface renewal analysis for sensible heat flux density using structure functions Agric. For. Meteorol. (1997) Vol. 86, pp. 259-271.

[32] VAN ATtA C.W., Effect of coherent structures on structure functions of temperature in the atmopheric boundary layer Arch. Of Mech. (1977) Vol. 29, pp. 161-171.

\section{SUMMARY}

Remote sensing techniques using high resolution satellite images provide opportunities to evaluate daily crop water use and its spatial and temporal distribution on a field by field basis. Mapping this indicator with pixels of few meters of size on extend areas allows to characterize different processes and parameters. Satellite data on vegetation reflectance, integrated with in field measurements of canopy coverage features and the monitoring of energy fluxes through the soil-plant-atmosphere system, allow to estimate conventional irrigation components $\left(\mathrm{ET}, \mathrm{K}_{\mathrm{c}}\right)$ thus improving irrigation strategies.

In the study, satellite potential evapotranspiration $\left(E_{p}\right)$ and crop coefficient $\left(K_{c}\right)$ maps of orange orchards are derived using semi-empirical approaches between reflectance data from IKONOS imagery and ground measurements of vegetation features. The monitoring of energy fluxes through the orchard allows to estimate actual crop evapotranspiration $\left(\mathrm{ET}_{\mathrm{a}}\right)$ using energy balance and the Surface Renewal theory. The approach indicates substantial promise as an efficient, accurate and relatively inexpensive procedure to predict actual ET fluxes and $\mathrm{K}_{\mathrm{c}}$ from irrigated lands.

Key words: Crop water requirements, Energy balance, Irrigation components, Remote sensing, Vegetation indice. 